\title{
The effects of supplementation with green tea waste on in vivo and in vitro rumen fermentation in cattle
}

\author{
M. Kondo ${ }^{1}$, K. Kita and H. Yokota \\ Graduate School of Bio-agricultural Sciences, Nagoya University, \\ Nagoya University Farm, Morowa \\ Togo, Aichi, 470-0151, Japan
}

\begin{abstract}
Ensiled green tea waste (GTW) was offered to growing cattle as a protein supplement compared to lucerne hay cube. Rumen fermentation was evaluated by in vivo rumen $\mathrm{pH}$, volatile fatty acids (VFA) and $\mathrm{NH}_{3}-\mathrm{N}$ as well as in vitro gas production from hay, maize, and soyabean meal. GTW contained about $340 \mathrm{~g} / \mathrm{kg}$ crude protein (CP), $90 \mathrm{~g} / \mathrm{kg}$ total extractable tannins and $14 \mathrm{~g} / \mathrm{kg}$ condensed tannins, and was offered as protein supplement to growing cattle. GTW silage made up $56 \mathrm{~g} / \mathrm{kg}$ $\mathrm{DM}$ and $130 \mathrm{~g} / \mathrm{kg} \mathrm{CP}$ of the diet in this performance trial. Gas production from maize incubated with rumen fluid of cattle fed GTW was reduced compared with cattle fed lucerne hay cube during 2 months. However, VFA and $\mathrm{NH}_{3}-\mathrm{N}$ concentrations of in vivo rumen were not affected and growth performance of cattle was similar to lucerne hay cube treatment. It is concluded that GTW silage could be used as protein supplement in a low proportion (about $50 \mathrm{~g} / \mathrm{kg} \mathrm{DM}$ and $130 \mathrm{~g} / \mathrm{kg} \mathrm{CP}$ of diet) in the ration for growing cattle.
\end{abstract}

KEY WORDS: green tea waste, protein supplement, tannin, rumen fermentation, in vitro gas production, cattle

\section{INTRODUCTION}

Tea is one of the world's most popular beverages, and more than 3 million tons of tea leaf were produced in 2002. In Japan, beverage companies manufacturing various tea drinks produce about 100 thousand tons of tea leaf waste annually. Green tea waste (GTW) contained $280 \mathrm{~g} / \mathrm{kg}$ DM of crude protein (CP) and 90 $\mathrm{g} / \mathrm{kg}$ DM of tannins (Kondo et al., 2004). Kondo et al. (2004) found that GTW has a potential of protein supplement for low-quality forages. However, it is still necessary to evaluate GTW as a feedstuff from the point of rumen fermentation.

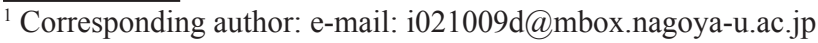


In this study, the activity of rumen fermentation in cattle fed GTW was assessed with parameters such as in vivo $\mathrm{pH}, \mathrm{NH}_{3}-\mathrm{N}$, volatile fatty acids (VFA) concentration and also in vitro gas production using rumen fluid obtained from the animals fed GTW. Simultaneously, growth performance in cattle fed GTW silage substituted with lucerne hay cube was investigated to evaluate the value of GTW as a protein supplement.

\section{MATERIAL AND METHODS}

\section{Animals and dietary treatments}

Ten Japanese Black beef cattle ( 6 female and 4 castrates) were divided into two groups (each group had 3 females and 2 castrates) and housed in two groups. At the start of the preliminary period, the mean body weight of the animals was 263.5 $\mathrm{kg}$. The diets were as follows:

a. Commercial concentrate plus timothy hay plus lucerne hay cube (LHC);

b. Commercial concentrate plus timothy hay plus GTW silage (GTWs).

Both treatments had the same amount of commercial concentrate and timothy hay. Lucerne hay cube or GTW silage was added as a protein supplement. The diets designed to satisfy the nutrient requirements of growing cattle were offered in fixed quantities. Rumen fluid was collected $4 \mathrm{~h}$ after the morning feed at month $0,0.5,1$ and 2 for $\mathrm{pH}, \mathrm{VFA}$ and $\mathrm{NH}_{3}-\mathrm{N}$ analysis as well as in vitro gas production.

\section{In vitro gas production experiment}

The degradation characteristics of timothy hay, maize and soyabean meal were measured by in vitro gas production technique (Menke et al., 1979). Two hundred mg sample ground to $1 \mathrm{~mm}$ screen was incubated in $100 \mathrm{ml}$ glass syringes with 30 $\mathrm{ml}$ buffered rumen fluid from the cattle fed experimental diets. The glass syringes containing samples and rumen fluid-buffer mixtures were incubated in a water bath at $39^{\circ} \mathrm{C}$, and subsequently gas production $(\mathrm{ml} / 200 \mathrm{mg} \mathrm{DM})$ was measured before incubation $(0 \mathrm{~h})$ and at $2,4,6,8,10,12,24,48$ and $72 \mathrm{~h}$ and fitted to the model described as $\mathrm{G}=\mathrm{a}+\mathrm{b}\left(1-\mathrm{e}^{-\mathrm{ct}}\right)$ (Ørskov and McDonald, 1979).

Table 1. Chemical compositions of feedstuffs

\begin{tabular}{lrccccc}
\hline Feed & $\begin{array}{r}\text { DM } \\
\mathrm{g} / \mathrm{kg}\end{array}$ & CP & NDF & $\begin{array}{r}\text { TEPH } \\
\mathrm{g} / \mathrm{kg} \mathrm{DM}\end{array}$ & TET & CT \\
\hline Timothy hay & 894 & 103 & 652 & 12.6 & 3.1 & 0.9 \\
Commercial concentrates & 885 & 184 & 299 & 4.4 & 0.9 & 0.1 \\
Lucerne hay cube & 884 & 176 & 426 & 7.2 & 1.3 & N.D. \\
GTW silage & 199 & 337 & 321 & 109.8 & 89.7 & 13.5 \\
\hline
\end{tabular}

TEPH- total extractable phenolics, TET- total extractable tannins, CT- condensed tannins, N.D.- not detected 


\section{RESULTS}

The chemical composition of the feedstuffs fed to growing cattle in experiment 2 is presented in Table 1. CP content in GTW was higher than in timothy hay, formulated commercial concentrates and lucerne hay cube. In this experiment, the amount of CP from lucerne hay cube or GTW silage covered $130 \mathrm{~g} / \mathrm{kg} \mathrm{CP}$ of the whole diets given to cattle. TET and CT contents in GTW silage were higher than in the other feedstuffs (Table 1). GTW silage was added at a rate of $56 \mathrm{~g} / \mathrm{kg} \mathrm{DM}$ of total feed in GTWs treatment. TET and CT concentrations of the whole diets given to cattle were 3.2 and $8.2 \mathrm{~g} / \mathrm{kg} \mathrm{DM}, 0.4$ and $1.2 \mathrm{~g} / \mathrm{kg}$ DM in LHC and GTWs treatments, respectively.

Table 2. In vitro gas production characteristics of timothy hay, maize and soyabean meal in beef cattle fed the diets with lucerne hay cube (LHC) or GTW silage (GTWs) on months $0,0.5,1$ and 2

\begin{tabular}{|c|c|c|c|c|c|c|c|}
\hline \multirow{2}{*}{ Month } & \multirow{2}{*}{ Diet } & \multicolumn{6}{|c|}{$\mathrm{a}+\mathrm{b}(\mathrm{ml})$} \\
\hline & & Timothy hay & & Maize & & Soyabean meal & \\
\hline \multirow[t]{2}{*}{0} & LHC & 56.6 & & 90.9 & & 51.3 & \\
\hline & GTWs & 60.2 & & 97.9 & + & 49.2 & \\
\hline \multirow[t]{2}{*}{0.5} & LHC & 70.6 & & 108.0 & & 62.8 & \\
\hline & GTWs & 59.6 & & 89.1 & + & 60.5 & \\
\hline \multirow[t]{2}{*}{1} & LHC & 60.5 & & 102.9 & & 69.5 & \\
\hline & GTWs & 60.3 & & 91.4 & * & 64.0 & \\
\hline \multirow[t]{2}{*}{2} & LHC & 69.9 & & 106.4 & & 67.7 & \\
\hline & GTWs & 57.0 & + & 94.4 & + & 53.6 & + \\
\hline
\end{tabular}

,$+{ }^{*}$ means of GTWs with these marks are significantly different from that of $\mathrm{LHC},+: \mathrm{P}<0.10$,

* $-\mathrm{P}<0.05$

Rumen $\mathrm{pH}, \mathrm{VFA}$ and $\mathrm{NH}_{3}-\mathrm{N}$ concentrations on months $0,0.5,1$ and 2, were not significantly different among the treatments on each month. Potential gas production $(\mathrm{a}+\mathrm{b})$ from maize incubated with rumen fluid of GTWs treatment tended to be lower $(\mathrm{P}<0.10)$ on months 0.5 and 2 , and significantly lower on month $1(\mathrm{P}<0.01)$ (Table 2). With incubated timothy hay and soyabean meal, no treatment differences were observed in months 0.5 and 1 , but in month 2 the gas production tended to be lower $(\mathrm{P}<0.10)$ on the GTWs treatment. The fractional rate of gas production from any substrate incubated with rumen fluid from both treatments was not significantly different. Although the experiment lasted three months, the body weight gain did not differ significantly between treatments. 


\section{DISCUSSION}

Although the in vitro gas production from the incubated feedstuffs, particularly maize, was decreased on the GTWs treatment, rumen parameters $(\mathrm{pH}$, VFA and $\mathrm{NH}_{3}-\mathrm{N}$ ) were not affected by GTW silage ingestion. One of the differences between LHC and GTWs treatment was the intake of tannins. Hervas et al. (2003) reported that rumen VFA and NH3-N concentration was not affected, but in vitro gas production and in sacco degradation of hay was decreased by tannin intake. The GTWs treatment resulted in higher amounts of tannins than the LHC treatment, but the amount was relatively lower than reported earlier (e.g., Hervas et al., 2003). We assume that the structure of tannins in GTW might be important for anti-nutritive effects. Another possibility is that in this study, the in vitro gas production might overestimate the effect occurring in vivo.

GTW silage contributed about $130 \mathrm{~g} / \mathrm{kg}$ of the total $\mathrm{N}$ intake. Growth performance in beef cattle supplemented with GTW silage was similar to that obtained with lucerne hay cube. These data suggest that GTW could be a useful protein supplement similar to lucerne hay cube. The suppression of in vitro gas production from several feedstuffs on the GTW treatment seems to have no relation to rumen VFA, $\mathrm{NH}_{3}-\mathrm{N}$ concentration and body weight gain.

\section{REFERENCES}

Hervás G., Frutos P., Javier Giraldez F., Mantecon A.R., Alvarez Del Pino M.C., 2003. Effect of different doses of quebracho tannins extract on rumen fermentation in ewes. Anim. Feed Sci. Tech. 109, 65-78

Kondo M., Kita K., Yokota H., 2004. Feeding value to goats of whole-crop oat ensiled with green tea waste. Anim. Feed Sci. Tech. 113, 71-81

Menke K.H., Raab L., Salewski A., Steingass H., Fritz D., Schneider W., 1979. The estimation of the digestibility and metablizable energy content of ruminant feedingstuffs from the gas production when they are incubated with rumen liquor in vitro. J. Agr. Sci. 93, 217-222

Ørskov E.R., McDonald I., 1979. The estimation of protein degradability in the rumen from incubation measurements weighted according to rate of passage. J. Agr. Sci. 92, 499-503 